\title{
https://doi.org/10.52240/1857-2367.2020.2(21).20 \\ GENUL CRATAEGUS L. ÎN FLORA BASARABIEI
}

\author{
Valentina CANTEMIR \\ Grădina Botanică Națională (Institut) "Alexandru Ciubotaru”, \\ Chișinău, Republica Moldova
}

\begin{abstract}
As a result of the critical analysis of the genus Crataegus L. (Rosaceae Juss.), it has been found that the flora of the researched region includes 6 species: C. pentagyna, C. ucrainica, C. microphylla, C. rhipidophylla, C. monogyna s. 1., C. $x$ dipyrena. The species C. pentagyna is mentioned in the Red Book of the Republic of Moldova, in the category - [Critically Endangered (CR)].
\end{abstract}

Key words: family, Rosaceae, genus, Crataegus, taxonomy, flora, Bessarabia.

Genul Crataegus L. (Păducel) este unul dintre cele mai complexe genuri, din punct de vedere taxonomic, din familia Rosaceae Juss. şi include de la 250-300 (Phipps, James, 1990) la 1500 de specii (Цвелев, 2001). Pentru flora R. Moldova Gheideman T. S. (Гейдеман, 1986) indică 8 specii spontane, iar acad. A. Negru (Negru, 2007) - 9 specii, de păducel. Prezența poliploidiei și apomixiei (Цвелев, 2001) determină o mare diversitate de tipuri morfologice de indivizi, ceea ce complică identificarea speciilor genului respectiv. De aceea, este esenţial ca materialul colectat în teren să fie divers, amplu şi, necesarmente, să conţină ramuri florifere şi fructifere. Reprezentanţii genului prezintă arbori sau arbuşti spinoşi, cu frunze lobate sau fidate până la sectate, pe margini serate, cu stipele persistente; răspândiți în special în regiunile temperate şi subtropicale ale Emisferei de Nord, preponderent în zona colinară şi montană, unde cresc în tufărişuri, păduri şi, mai rar, pe versanţi de stepă.

În urma prelucrării critice a materialelor erborizate de păducel, din colecţia herbarului GBNI, efectuată în legătură cu editarea monografiei „Flora Basarabiei”, a fost stabilit că pe teritoriul florei regiunii cercetate se întâlnesc 6 specii din genul Crataegus L.

1. C. pentagyna Waldst. \& Kit. 1800, in Willd., Sp. P1. 2, 2: 1006.

Arbore, înfloreşte în mai-iunie, fructifică în august-septembrie; $2 n=34$. Specie silvicolă, vegetează prin poiene, margini de păduri, tufărişuri; răspândită rar în districtele din centrul şi sudul teritoriului. Specie Critic periclitată [CR], inclusă în Cartea Roşie a R. Moldova şi în Lista speciilor ocrotite de stat. Element Pont-Pan-Balc., arealul cuprinde Caucazul, Europa de Sud-Est, regiunea mediteraneană (Balc.), Asia Mică.

2. C. ucrainica Pojark. 1939, Фл. СССР, 9: 502, 441.

Arbust, arbore, înfloreşte în iunie, fructifică în august-septembrie. Specie silvicolă, vegetează prin poiene, margini de păduri, tufărişuri; răspândită rar în districtele cu păduri de gorun şi de stejar cu carpen. Element Euc., cu areal în Europa Centrală şi Sud-Est. Prezentă în Lista Roşie a speciilor ameninţate UICN.

3. C. microphylla K. Koch, 1853, Verh. Vereins Beförd. Gartenb. Konigl. Preuss. Staaten Ser. 2, 1: 288.

Arbust, înfloreşte în mai-iunie, fructifică în august-octombrie; $2 n=32$, 34. Specie silvicolă, vegetează prin poiene, margini de păduri de gârneţ, tufărişuri; răspândită rar în zona silvostepei din stânga Prutului de mijloc. Element Eurasiatic, arealul cuprinde Crimeea, Caucazul, Turcia, Iranul. 
4. C. rhipidophylla Gand. 1871, Bull. Soc. Bot. France, 18: 447. - C. oxyacantha L. 1753, Sp. P1.: 477, nom. rejic. - C. curvisepala Lindm. 1918, Sv. Fanerogamfl.: 307, fig. 189, nom. superfl. - C. pseudokyrtostyla Klokov, 1954, Фл. УРСР, 6: 574.

Arbust, arbore, înfloreşte în mai-iunie, fructifică în august-octombrie; 2n=34, 51, 68. Specie silvicolă, vegetează prin păduri, poiene, margini de păduri, tufărişuri; se întâlneşte aproape pe întreg teritoriul „Florei”. Element Eur (Balc); arealul cuprinde Caucazul, Peninsula Scandinavă (sud), Europa Centrală şi de Sud, regiunea mediteraneană (Balcani), Asia Mică.

5. C. monogyna Jacq. s. 1., 1775, Fl. Austr. 3: 50, 292, tab. 292, fig. 1. - C. lipskyi Klokov, 1954, Фл. УРСР, 6: 577. - C. fallacina Klokov, 1954, Фл. УРСР, 6: 576. - C. leiomonogyna Klokov, 1954, Фл. УРСР, 6: 578. - C. monogyna subsp. leiomonogyna (Klokov) Franco, 1968, Feddes Repert. 79, 1-2: 37. - C. praearmata Klokov, 1954, Фл. УРCP, 6: 578.

Specie foarte polimorfă, cu indivizi care manifestă criterii taxonomice de trecere şi nu prezintă arealuri bine conturate, delimitate. Considerăm oportună tratarea speciei respective în sensu lato. Arbust, arbore, înflorește în mai-iunie, fructifică în augustoctombrie; $2 n=34$. Silvicolă, vegetează prin păduri, poiene, margini de păduri, tufărişuri; se întâlneşte în districtele din partea de nord, centru şi de sud a teritoriului. Element Eur-Medit., arealul cuprinde Caucazul, Peninsula Scandinavă (sud), Europa Atlantică şi Centrală, regiunea mediteraneană.

6. C. $\boldsymbol{x}$ dipyrena Pojark. 1939, Фл. СССР, 9: 508, 462 (C. pentagyna Waldst. et Kit. x C. monogyna Jacq.).

Arbust, înfloreşte în mai, fructifică în august-octombrie. Specie silvicolă, vegetează prin tufărişuri, margini de păduri; se întâlneşte rar în districtele din partea de sud a teritoriului (silvostepa de gârneţ). Element endemic, arealul cuprinde Crimeea, Europa de Sud-Est.

Cercetările au fost realizate cu suportul ANCD în cadrul proiectului „Cercetarea și conservarea florei vasculare și macromicobiotei din Republica Moldova”, cifrul 20.80009.7007.22 (contract de finanțare Nr. 71/PS/2020).

\section{BIBLIOGRAFIE}

1. Phipps I., James B. A checklist of the subfamily Maloideae (Rosaceae), Eds J. B. Phipps, K.R. Robertson, P. G. Smith, J. R. Rohrer, 1990, vol. 68, issue 10, pp. 2209-2269.

2. Negru A. Determinator de plante din flora Republicii Moldova. Chișinău, Edit. Universul, 2007, $391 \mathrm{p}$.

3. Гейдеман Т. С. Определитель высших растений Молдавской ССР. Кишинев, Штиинца, 1986, $637 \mathrm{c}$.

4. Цвелев Н. Н., Crataegus L. // Флора Восточной Европьл. - СПб: Мир и семья, изд-во СПХФА, 2001. T. 10. C. 557-586. 